\title{
Age of the Emeishan flood magmatism and relations to Permian-Triassic boundary events
}

\author{
Ching-Hua Lo ${ }^{\mathrm{a}, *}$, Sun-Lin Chung ${ }^{\mathrm{a}}$, Tung-Yi Lee ${ }^{\mathrm{b}}$, Genyao $\mathrm{Wu}^{\mathrm{c}}$ \\ a Department of Geosciences, National Taiwan University, 245 Choushan Road, Taipei 106, Taiwan \\ b Department of Earth Sciences, National Taiwan Normal University, Taipei, Taiwan \\ c Institute of Geology and Geophysics, Chinese Academy of Sciences, Beijing, PR China
}

Received 27 June 2001; received in revised form 12 February 2002; accepted 13 February 2002

\begin{abstract}
The Permian-Triassic (P-T) mass extinction, the greatest biological mortality event in the Earth's history, was probably caused by dramatic and global forcing mechanisms such as the Siberian flood volcanism. Here we present the first set of high-precision ${ }^{40} \mathrm{Ar} /{ }^{39} \mathrm{Ar}$ dating results of volcanic and intrusive rocks from the Emeishan Traps, South China, which define a main stage of the flood magmatism at $\sim 251-253 \mathrm{Ma}$ and a subordinate precursory activity at $\sim 255 \mathrm{Ma}$. This time span is generally coeval with, or slightly older than, the age of the P-T boundary estimated by the ash beds in the Meishan stratotype section and the main eruption of the Siberian Traps. Our data reinforces the notion that the eruption of the Emeishan Traps, rather than eruption of the Siberian Traps, accounted for the formation of the P-T boundary ash beds in South China. The Emeishan flood magmatism, which occurred in the continental margin comprising thick marine limestone formations, moreover, may have triggered rapid release of large volumes of methane and carbon dioxide that could have been responsible for the global $\delta^{13} \mathrm{C}$ excursion and associated environmental crisis leading to the mass extinction at the P-T boundary. (C) 2002 Elsevier Science B.V. All rights reserved.
\end{abstract}

Keywords: flood basalts; South China Block; Permian-Triassic boundary; mass extinctions; Ar-40/Ar-39

\section{Introduction}

Mass extinction at the Permian-Triassic (P-T) boundary was the most profound event in the history of life on Earth. Nearly $90 \%$ of all species in the ocean and $70 \%$ of vertebrate genera on the continent vanished by the end of Paleozoic Era $[1,2]$. Traditionally, paleontologists believe that

\footnotetext{
* Corresponding author. Tel.: +886-2-2363-5880; Fax: +886-2-2363-6095.

E-mail address: loch@ccms.ntu.edu.tw (C.-H. Lo).
}

this biologic great dying was slow, lasting at least several million years $[1,2]$ and even occurred as two or more separate events [3,4]. Causes for such a prolonged extinction are therefore hypothesized to have been gradual processes such as sea level fall and climate change. To constrain the tempo of the end-Permian extinction, Bowring et al. [5] conducted a detailed U-Pb zircon geochronological study of the P-T marine boundary sections in Meishan, South China, and placed the P-T boundary at Bed 25 that was dated to be $251.4 \pm 0.3 \mathrm{Ma}$. Combining biostratigraphic information [5-7] and the negative excursion in $\delta^{13} \mathrm{C}$ 
across the boundary [5,7], these authors furthermore suggested that the Changhsingian pulse of the end-Permian extinction was rapid and lasted less than 1 Myr. Such rapidity, however, has been recently questioned by Mundil et al. [8] based on new $\mathrm{U}-\mathrm{Pb}$ zircon data from the same boundary layers. The age of Bed 25 has been redefined to be $\sim 254 \mathrm{Ma}$ and the P-T boundary moved to Bed 27 (Fig. 1A), which should be slightly older than Bed 28 dated as $252.5 \pm 0.3 \mathrm{Ma}$ [8]. Thus, the main stage of the end-Permian extinction occurred at $\sim 253 \mathrm{Ma}$ and the $\delta^{13} \mathrm{C}$ excursion appears to be significantly longer than previously postulated (Fig. 1A).

Among numerous scenarios proposed to explain the P-T extinction [1-5], the Siberian flood volcanism that represents the largest subaerial volcanic event in the Phanerozoic record has been most widely accepted. U-Pb and ${ }^{40} \mathrm{Ar} /{ }^{39} \mathrm{Ar}$ dating investigations [6,9-12] repeatedly argued that emplacement of the immense Siberian Traps $\left(>2.5 \times 10^{6} \mathrm{~km}^{2}\right.$ in area) took place at the $\mathrm{P}-\mathrm{T}$ boundary. Campbell et al. [9] proposed that eruption of the Siberian Traps injected vast volumes of volcanic dust and sulfate aerosols into the atmosphere, a process that could have caused a short-lived volcanic winter. This volcanic winter, according to the hypothesis by Renne et al. [11], was followed within several hundred thousand years by greenhouse conditions because the eruption would have also released large amounts of volcanogenic gases composed primarily of $\mathrm{CO}_{2}$. Such a cooling-warming climate cycle could have resulted in an environmental crisis capable of causing the fierce mass extinction [6,9-12].

Being one of the large igneous provinces that occurred also around the P-T boundary [13,14], the eruption of the Emeishan Traps, South China, and its relations to the boundary events have at- tracted numbers of recent investigations [15-20]. In this paper, we report the first set of high quality ${ }^{40} \mathrm{Ar} /{ }^{39} \mathrm{Ar}$ dating results of representative samples from the Emeishan Traps, which define a main phase of the Emeishan flood magmatism at $\sim 251-253 \mathrm{Ma}$ and an earlier, but subordinate, phase at $\sim 255 \mathrm{Ma}$. These age data are generally coincident with, or slightly older, if considering all the potential systematic errors between the ${ }^{40} \mathrm{Ar} /$ ${ }^{39} \mathrm{Ar}$ and $\mathrm{U}-\mathrm{Pb}$ methods, than the ages of the $\mathrm{P}-\mathrm{T}$ boundary at Meishan and the Siberian Traps. This time sequence supports the hypothesis that the Emeishan eruption, in particular its later phase of felsic composition, could have accounted for the widespread deposition of the P-T boundary ash layers in South China. Given the fact that the Emeishan Traps were emplaced around the continental margin underlain by thick limestone formations, the vast eruption in a 'marine' environment is proposed to have played a key role in triggering the profound biogeochemical changes across the $\mathrm{P}-\mathrm{T}$ boundary.

\section{The Emeishan Traps}

In South China, P-T boundary stratotype sections that contain abundant interbedded volcanic ash layers are widespread [5,6,21]. Owing essentially to the synchronism between the Meishan ash beds and the Siberian flood volcanism, Campbell et al. [9] speculated that these boundary ash layers are genetically linked to the Siberian eruption despite the fact that they were deposited several thousand kilometers in the south around the equator (Fig. 1A) [16]. The P-T boundary ash layers in South China are characterized by concentrations of volcanogenic microspherules and bipyramid quartz grains [21]. Based on geochem-

Fig. 1. (A) At $\sim 253 \mathrm{Ma}$, the Siberian Traps were emplaced in the Arctic area, whereas the Emeishan Traps and Meishan P-T boundary ash beds (star) occurred in South China near the equator. The paleogeographic reconstruction is taken from Courtillot et al. [16] and inset for the Meishan section and relevant data is adopted from Mundil et al. [8]. (B) Outcrops of the Emeishan Traps in the western South China Block (black areas) and associated volcanic rocks in the Songpan-Ganze and Qiangtang terranes [14,15]. Insets illustrate distribution of major terranes in East Asia and two volcanic sections (Ertan and Bingchuan) of the Traps [23] from which samples were collected for this study. In the central part of the Emeishan Traps, close to the Ertan section, $\mathrm{M}$ and $\mathrm{P}$ indicate the locations of two large intrusions (Maomaogou and Panzhihua) from which the dated syenites were collected. 

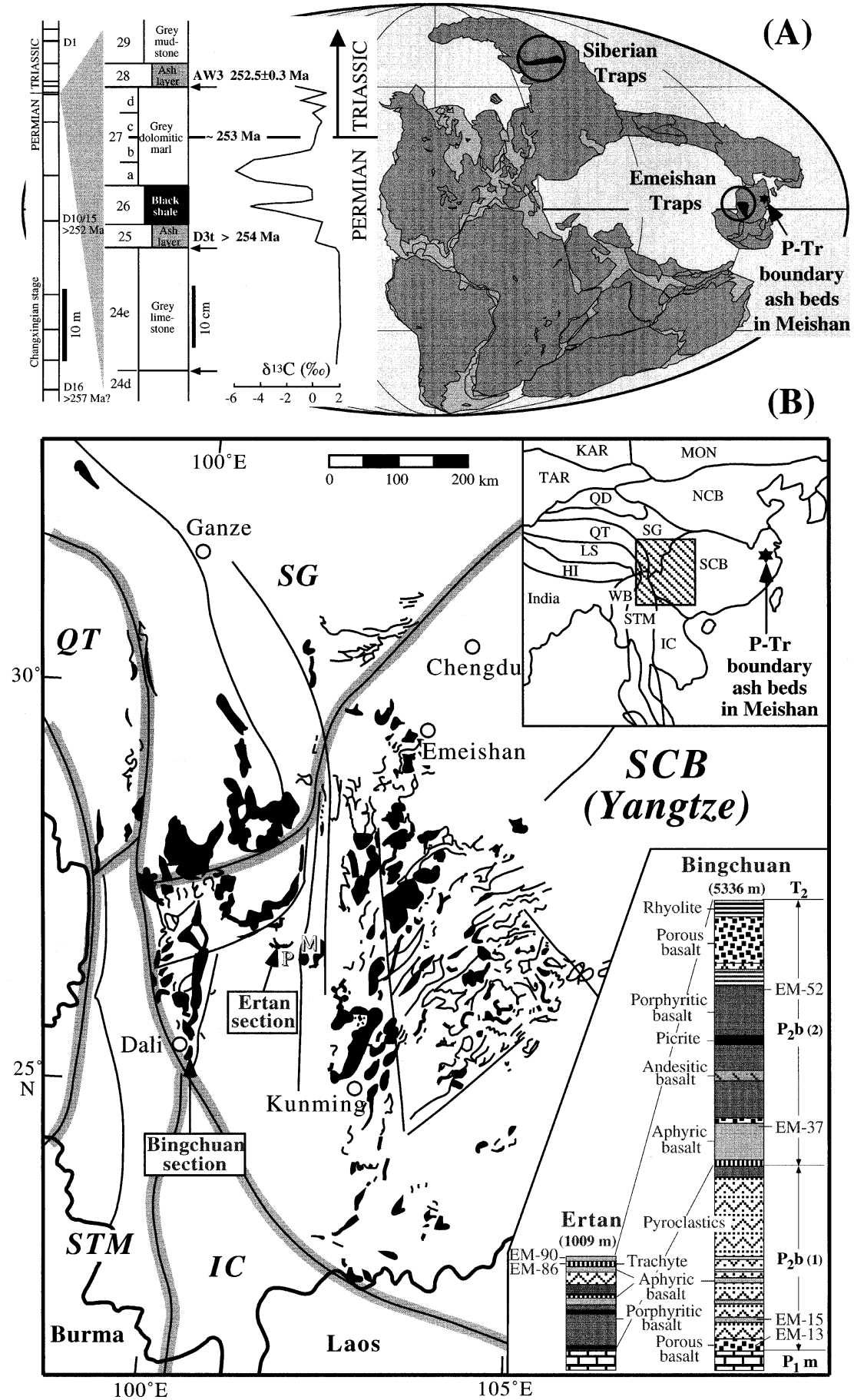

Major terranes of the East Asian continent:

$S C B=$ South China Block; SG= Songpan-Ganze Accretionary Complex;

$Q T=$ Qiangtang; STM= Shan-Thai-Malay; IC= Indochina;

$\mathrm{WB}=$ West Burma; HI= Himalaya; $\mathrm{LS}=$ Lhasa; $\mathrm{QD}=$ Qaidam;

$\mathrm{TAR}=$ Tarim; $\mathrm{KAR}=$ Karakorum $; \mathrm{MON}=$ Mongolia; $\mathrm{NCB}=$ North China Block. 
ical data, Zhou and Kyte [22] proposed that these ash layers resulted from massive silicic eruptions from a nearby region, which have been ascribed to flood volcanism in the Emeishan (basalt) Traps occurring in the western part of the South China Block [15] (Fig. 1B).

The Emeishan Traps, a large igneous province formed by a mantle plume head [14], are generally referred to as erosion remnants of the $\mathrm{P}-\mathrm{T}$ massive volcanic successions which occurred predominantly as mafic lava flows and pyroclastics in the western Yangtze (South China), Songpan-Ganze and eastern Qiangtang terranes [15,18-20] (Fig. 1B). The volcanic successions, tilted and fragmented by complicated tectonic events during Meso-Cenozoic times, are exposed in a rhombic area of $\sim 2.5 \times 10^{5} \mathrm{~km}^{2}(500 \times 500 \mathrm{~km})$ in association with numerous intrusive bodies of ultramafic/mafic to felsic compositions. The volcanic sequence thickness ranges from $\sim 5 \mathrm{~km}$ in the Bingchuan section (Fig. 1B) in the southwestern part of the Traps to several hundred meters in the eastern margin. The Emeishan flood basalts show spatial and temporal variations. The basaltic lavas can be divided into two major groups, i.e., the upper group with high-Ti $\left(\mathrm{TiO}_{2}>3.5 \mathrm{wt} \%\right)$ and the lower group with low-Ti $\left(1.5>\mathrm{TiO}_{2}>2.5\right.$ $w t \%)$ compositions [23]. Lavas of the low-Ti group are confined to the lower volcanic successions in the western part of the Traps, whereas lavas of the high-Ti group occur as the predominant component in the upper succession in nearly the entire region [23]. In localities, thick piles of trachyte and/or rhyolite form an important member in the upper sequence. The successions unconformably overlie the early Late Permian Maokou Formation (composed mainly of marine limestones corresponding to the Capitanian/Kazanian stage) and underlie the lower Triassic clastic sediments $[15,18,26]$. On the basis of magnetobiostratigraphic correlations, eruption of the traps was traditionally accepted to have taken place in the Late Permian, despite that previous geochronological data revealed a very scattered duration of $\sim 40-260 \mathrm{Ma}[20,24-26]$. There are numerous intrusive bodies exposed in the Emeishan Traps. These intrusions range from ultramafic and mafic to felsic compositions, some of the mafic bodies associated with large $\mathrm{V}-\mathrm{Ti}-\mathrm{Fe}$ ore deposits [15,24-26]. Gabbros and syenites from the Maomaogou and Panzhihua complexes (Fig. 1B) possess geochemical and $\mathrm{Sr}-\mathrm{Nd}$ isotopic compositions comparable to those of the nearby basalts and trachytes-rhyolites, respectively, strongly suggesting a genetic link between the intrusive and volcanic rocks in the Emeishan Traps [15,23]. Recently, a SHRIMP U/Pb zircon dating study was carried out for two of the gabbro-peridotite intrusions, yielding crystallization ages of $258.7 \pm 1.5$ and $256.0 \pm 1.0 \mathrm{Ma}$ [17]. However, these are still indirect age constraints inferred from the intrusive rocks whose exact time relation with the main stage of the Emeishan eruption is unknown. Precise dating directly on the volcanic successions is hence highly desirable.

\section{Analytical methods}

Six whole-rock samples from basaltic flows, hornblende and biotite separates from a trachyte flow and two syenite bodies, respectively, were dated by ${ }^{40} \mathrm{Ar} /{ }^{39} \mathrm{Ar}$ step-heating and single-grain fusion methods using furnace and laser heating techniques. Samples were first crushed and disintegrated. After sieving, mineral grains and rock chips in the range of $140-250 \mu \mathrm{m}$ were ultrasonically cleaned in distilled water and dried, and then handpicked to remove any visible contamination before further mineral separation. The samples were then irradiated together with the LP-6 biotite standard [27] in the VT-C position at the THOR Reactor in Taiwan for $10 \mathrm{~h}$ (EM-90 basalt); $24 \mathrm{~h}$ (EM-86 hornblende, EM-PZH01 biotite and EM-13 and EM-15 basalts); and $30 \mathrm{~h}$ (the remaining samples). In order to monitor the neutron flux in the reactor, three aliquots of the LP-6 standard, weighted in the range of $6 \sim 10 \mathrm{mg}$, were stacked with samples in each irradiation package with a length of $\sim 9 \mathrm{~cm}$. After irradiation, standards and samples were either incrementally heated or totally fused using a double-vacuum resistance furnace and/or a US LASER NdYAG laser operated in continuous mode, and the gas was measured by a VG3600 mass spectrometer at the National Taiwan University. The $J$ val- 


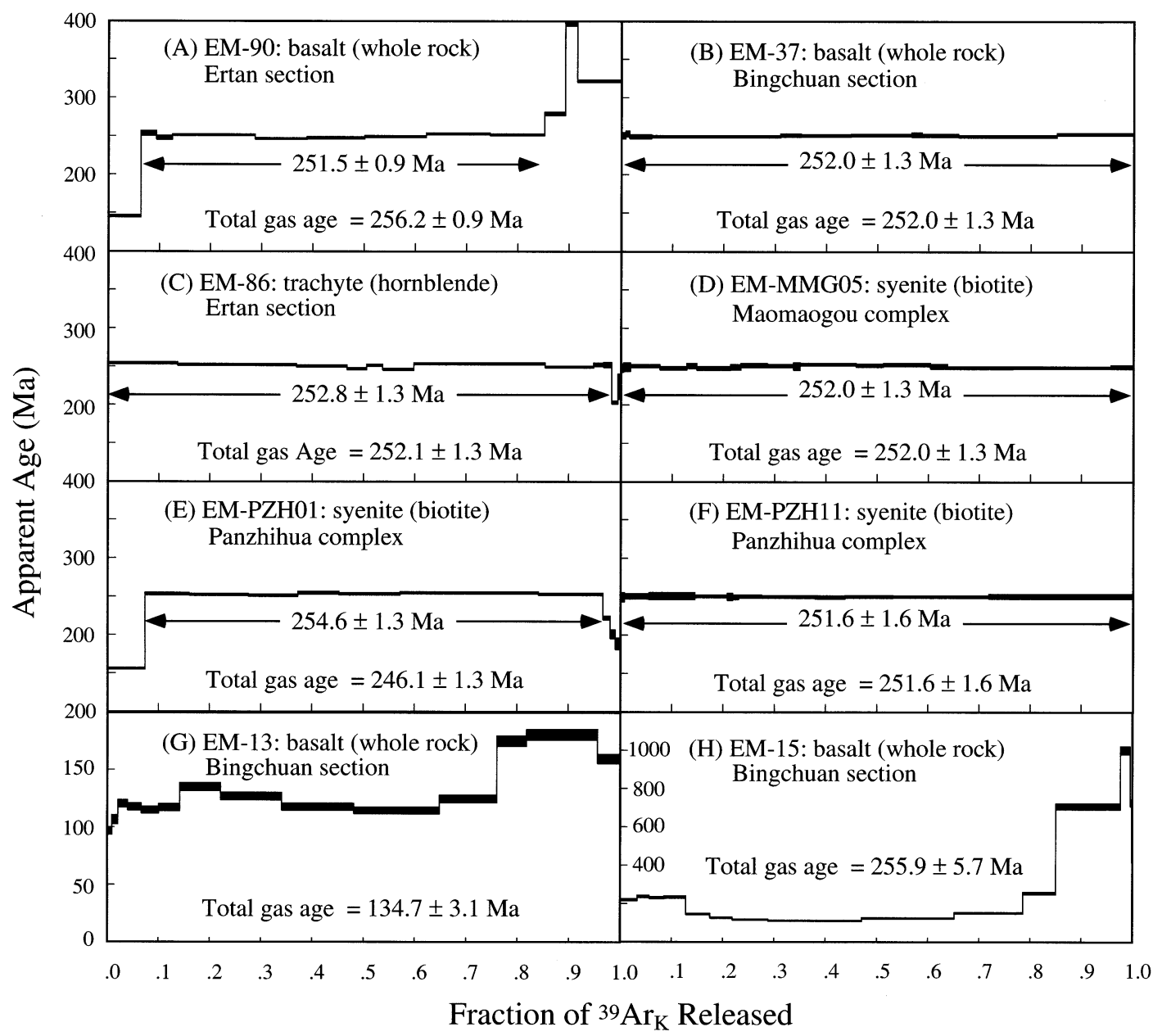

Fig. 2. Apparent age spectra of the step-heating analyses for: (A,B) two high-Ti basalts (whole rock), (C) a trachyte (hornblende), (D-F) three syenites (biotites) and (G,H) two low-Ti basalts from the Emeishan Traps. Plateau ages are calculated within arrows, which indicate gas fractions used for plateau age calculations. The vertical height of each step, shown as black horizontal bar, represents $2 \sigma$ external error. All errors shown are $1 \sigma$ which include uncertainties derived from the age of the irradiation standard.

ues are calculated using argon compositions of the LP-6 biotite standard, with a ${ }^{40} \mathrm{Ar} /{ }^{39} \mathrm{Ar}$ age of $128.4 \pm 0.2 \mathrm{Ma}$, calibrated according to the age of the Fish Canyon biotite by assuming that has the same age as the Fish Canyon sanidine $(28.02 \pm 0.28 \mathrm{Ma})[12,28]$. Ages were calculated from $\mathrm{Ar}$ isotopic ratios measured after corrections made for mass discrimination, interfering nuclear reactions, procedural blanks, and atmospheric $\mathrm{Ar}$ contamination. Detailed results of the ${ }^{40} \mathrm{Ar} /{ }^{39} \mathrm{Ar}$ experiments of this study are given in tables 1 and 2 of the Background Data Set $^{1}$, and the data are plotted as age spectra and in isotope correlation diagrams in Figs. 2 and 3.

\section{Analytical results}

For the basaltic rocks, two samples (EM-37

\footnotetext{
1 http://www.elsevier.com/locate/epsl
} 


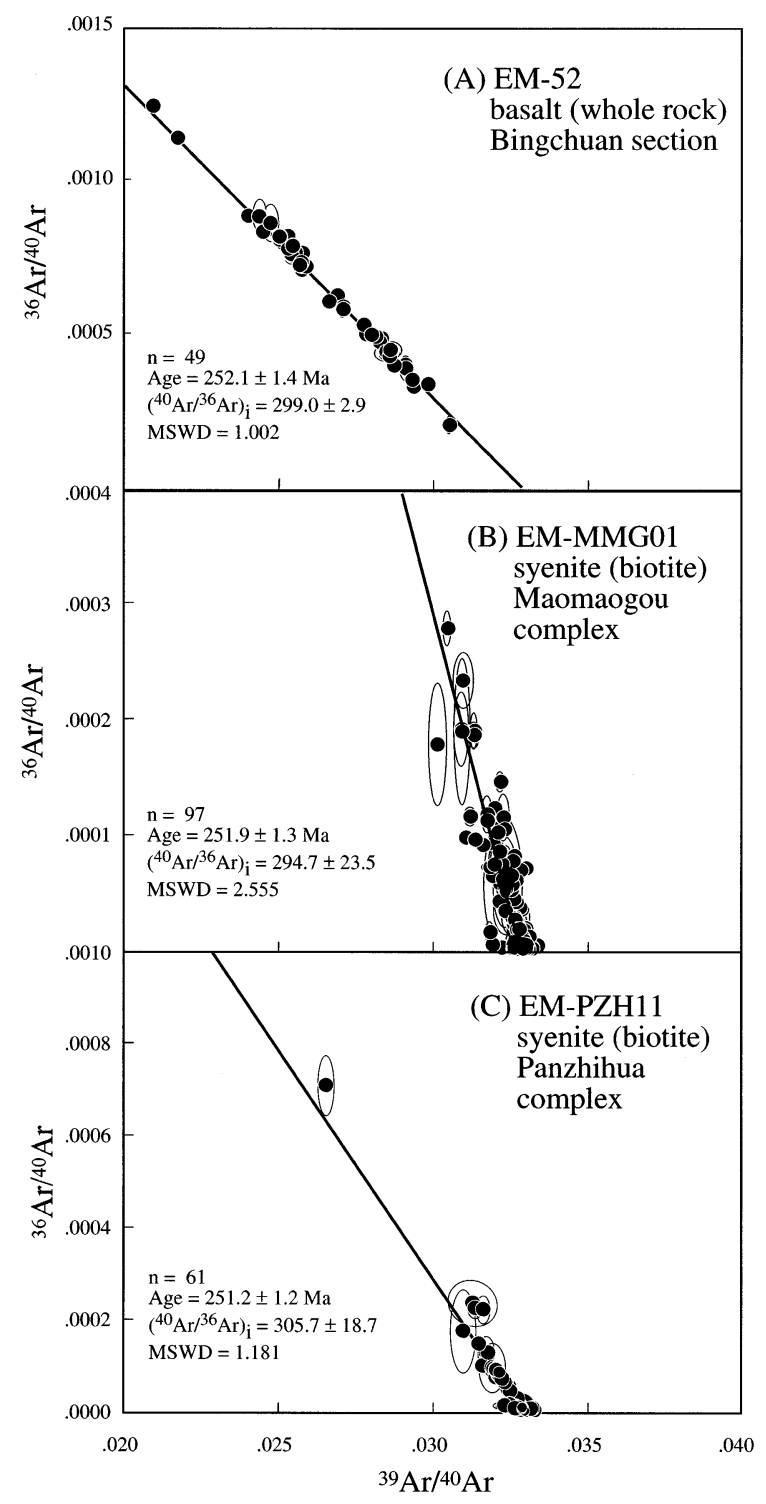

Fig. 3. ${ }^{36} \mathrm{Ar} /{ }^{40} \mathrm{Ar}-{ }^{39} \mathrm{Ar} /{ }^{40} \mathrm{Ar}$ isotope correlation diagrams for: (A) a whole-rock basalt, and (B,C) biotite separates from two syenites, obtained by single-grain laser fusion experiments. Individual data points are presented by solid circles, with $\pm 1 \sigma$ error ellipses.

and EM-52) were from the upper part of the Bingchuan section and one (EM-90) from the top of the Ertan section; the latter sample was collected from the flow that underlies mid-Triassic clastic formations and overlies a thick $(\sim 80 \mathrm{~m})$ trachyte flow (Fig. 1B). These three samples be- long to the high-Ti basalt group that represents the main eruption in the upper sequence of the Emeishan Traps. ${ }^{40} \mathrm{Ar} /{ }^{39} \mathrm{Ar}$ step-heating analyses of the whole-rock samples of EM-90 and EM-37 yielded flat age spectra with identical plateau ages of $251.5 \pm 0.9$ and $252.0 \pm 1.3 \mathrm{Ma}$, respectively (Fig. 2A,B). In the ${ }^{36} \mathrm{Ar} /{ }^{40} \mathrm{Ar}$ versus ${ }^{39} \mathrm{Ar} /{ }^{40} \mathrm{Ar}$ correlation diagrams, the data of both samples define linear arrays with reasonable values of the mean square of the weighted deviates (MSWD; 2.501 for EM-90 and 0.998 for EM-37). The intercept ages and ${ }^{40} \mathrm{Ar} /{ }^{39} \mathrm{Ar}$ initial ratios, $251.2 \pm 1.3 \mathrm{Ma}$ and $299 \pm 28$ for EM-90 and $252.7 \pm 1.6 \mathrm{Ma}$ and $291.0 \pm 5.3$ for EM-37, are consistent with their respective plateau ages and the atmospheric ${ }^{40} \mathrm{Ar} /{ }^{36} \mathrm{Ar}$ ratio (295.5). Excess argon is not apparent despite that alteration might have occurred in sample EM-90, as reflected by some minor disturbances in the age spectrum. On the other hand, laser fusion experiments on the whole-rock sample of EM-52 gave apparent dates $(n=49)$ in the range of 249.0 $255.6 \mathrm{Ma}$ with a total gas age of $252.8 \pm 1.3 \mathrm{Ma}$, and yielded an intercept age of $252.1 \pm 1.4$ $\mathrm{Ma}$ and ${ }^{40} \mathrm{Ar} /{ }^{36} \mathrm{Ar}$ initial value of $299 \pm 3$ $(\mathrm{MSWD}=1.002) \quad($ Fig. 3A). This intercept age, in consideration with the data distribution and individual errors, is in good agreement with the two plateau dates obtained by the step-heating experiments. Moreover, a trachyte (EM-86) that underlies sample EM-90 from the Ertan section (Fig. 1B) was dated using hornblende separates and yielded a plateau age of $252.8 \pm 1.3 \mathrm{Ma}$ (Fig. 2C), and an intercept age and ${ }^{40} \mathrm{Ar} /{ }^{36} \mathrm{Ar}$ initial value of $252.6 \pm 1.6 \mathrm{Ma}$ and $285 \pm 49$, respectively. These dating results indicate that the main eruption of the Emeishan Traps, constrained by the upper Bingchuan ( $3000 \mathrm{~m}$ thick) and Ertan $(\sim 1000 \mathrm{~m})$ sections, was of short duration between $\sim 251-253 \mathrm{Ma}$.

Biotite separates from two large syenite intrusions in the Maomaogou and Panzhihua complexes, close to Ertan (Fig. 1B), were also dated by the ${ }^{40} \mathrm{Ar} /{ }^{39} \mathrm{Ar}$ method. These include furnace step-heating analyses of a Maomaogou sample (EM-MMG05) and two Panzhihua samples (EM-PZH01 and 11) (Fig. 2D-F) and single-grain laser fusion analyses of a biotite sample from each 
complex (EM-MMG01 and EM-PZH11) (Fig. 3B,C). Sample EM-PZH11 was dated by both step-heating and total fusion methods. In the step-heating analyses, all three samples show flat age spectra with $>87 \%$ of ${ }^{39} \mathrm{Ar}_{\mathrm{K}}$ released. The Maomaogou sample (EM-MMG05) and one of the Panzhihua samples (EM-PZH11) yielded identical plateau ages of $252.0 \pm 1.3$ and $251.6 \pm 1.6$ Ma (Fig. 2D,F), respectively, whereas another Panzhihua sample (EM-PZH01) gave a slightly older plateau age of $254.6 \pm 1.3 \mathrm{Ma}$ (Fig. 2E). In the isotope correlation diagrams, the intercept ages and ${ }^{40} \mathrm{Ar} /{ }^{36} \mathrm{Ar}$ initial values are $251.4 \pm 1.9$ $\mathrm{Ma}$ and $312 \pm 37$ (EM-MMG05), 251.4 $\pm 1.2 \mathrm{Ma}$ and $303 \pm 5$ (EM-PZH11), and 254.9 $\pm 1.5 \mathrm{Ma}$ and $291 \pm 33$ (EM-PZH01), all in excellent agreement with their respective plateau ages and the atmospheric composition. The laser fusion analyses gave similar intercept ages of $251.9 \pm 1.3 \mathrm{Ma}$ (EM-MMG01) and 251.2 \pm 1.2 Ma (EMPZH11), both with reasonable ${ }^{40} \mathrm{Ar} /{ }^{36} \mathrm{Ar}$ initial ratios and MSWD values (Fig. 3B,C). The data of sample EM-PZH11 obtained by two independent procedures match fairly well, indicating good reproducibility and accuracy. These biotite ${ }^{40} \mathrm{Ar} /$ ${ }^{39} \mathrm{Ar}$ dates support the conclusion reached by the whole-rock dating results that the major stage of the Emeishan magmatism took place in a short period of $\sim 251-253 \mathrm{Ma}$. The relatively older date of $254.6 \pm 1.3 \mathrm{Ma}$ for EM-PZH01 biotite, therefore, may imply an earlier intrusion that occurred $\sim 255 \mathrm{Ma}$. This appears to be consistent with the notion by the SHRIMP U-Pb zircon dating results [17], which suggest the Emeishanrelated magmatism to have started as early as 256-258 Ma. However, the interval between these intrusions and the main phase of the Emeishan eruption remains unclear and requires more detailed investigations.

We also dated some low-Ti group basaltic lavas (e.g., EM-13 and -15; Fig. 1B) from the lower volcanic sequences. However, no statistically meaningful ${ }^{40} \mathrm{Ar} /{ }^{39} \mathrm{Ar}$ dating results can be obtained. Both samples EM-13 and EM-15 yielded disturbed age spectra with wide ranges of ${ }^{40} \mathrm{Ar} /$ ${ }^{39} \mathrm{Ar}$ apparent ages (Fig. 2G,H). Similar disturbed age spectra have also been reported in a recent ${ }^{40} \mathrm{Ar} /{ }^{39} \mathrm{Ar}$ dating study on the Emeishan rocks
[20]. Considering that these low-Ti samples are fresh in terms of petrography and geochemistry [23], we tentatively ascribe such serious disturbance features in the Ar systematics to the very complicated Meso-Cenozoic tectonothermal history of this area $[15,20]$, which, in particular, includes intensive crustal deformation and magmatic activity related to the India-Asia collision [29]. Therefore, the initiation age of the Emeishan flood volcanism has yet been accurately constrained and further works including careful and detailed sampling and high-precision dating of the early phase of this volcanism are anticipated to be done.

\section{Discussion and conclusion}

The above results lead us to conclude that the main stage of the Emeishan magmatism took place in a short duration of $\sim 251.2-252.8 \mathrm{Ma}$ (with errors in the range of $\pm 1.3-1.6 \mathrm{Ma}$ ). This age span appears to be slightly older than the principal activity of the Siberian Traps, defined by the recalculated ${ }^{40} \mathrm{Ar} /{ }^{39} \mathrm{Ar}$ ages of basaltic flows $(249.9 \pm 0.2 \mathrm{Ma})$ and the Norils'k intrusion $(250.0 \pm 0.2 \mathrm{Ma})$ [12]. Moreover, the older date $(254.6 \pm 1.3 \mathrm{Ma})$ of the Panzhihua syenite (EM$\mathrm{PZH} 01)$ implies a precursory intrusion that may have accompanied the eruption of the lower volcanic sequence in the Bingchuan section. More mafic intrusions may have occurred in the nearby region, as revealed by the $\mathrm{U}-\mathrm{Pb}$ zircon data [17], suggesting magmatic activity around $256 \sim 258$ Ma. Such precursory magmatism that forms as the earliest manifestation of a mantle plume has been documented to have occurred several million years before the flood volcanism in the Siberian Traps [30] and the end-Cretaceous Deccan Traps in India [31]. The precursory Siberian magmatism in the Maimecha-Kotui subprovince, dated at $253.3 \pm 2.6 \mathrm{Ma}$ [30], has been considered responsible for initiating the marked decrease in seawater ${ }^{87} \mathrm{Sr} /{ }^{86} \mathrm{Sr}$ (to values $<0.707$ ) that took place before the $\mathrm{P}-\mathrm{T}$ boundary by assuming that the decrease in seawater ${ }^{87} \mathrm{Sr} /{ }^{86} \mathrm{Sr}$ reflects an increasing mantle-derived component and no evidence exists for a heightened mid-ocean ridge basalt ac- 
tivity at this time [11]. In comparison to the within-continent occurrence of the Siberian Traps, the Emeishan magmatism, which occurred in the western continental margin of the South China Block along the Panthalassan and Tethyan margins can serve as an even better candidate for the seawater ${ }^{87} \mathrm{Sr} /{ }^{86} \mathrm{Sr}$ decrease. In the lower sequence in the Bingchuan section, basaltic flows are marked by pillow structures indicative of a submarine eruption environment [15,24,25].

Compared to the $\mathrm{P}-\mathrm{T}$ stratotype section at Meishan, the ${ }^{40} \mathrm{Ar} /{ }^{39} \mathrm{Ar}$ ages $(\sim 251-253 \mathrm{Ma})$ of the main stage of the Emeishan magmatism are slightly older than the ${ }^{40} \mathrm{Ar} /{ }^{39} \mathrm{Ar}$ age of Bed 25 dated as $250.0 \pm 0.2 \mathrm{Ma}$ [6] but seem to match in face values with the $\mathrm{P}-\mathrm{T}$ boundary age ( 253 Ma) newly defined at Bed 27 (Fig. 1A) by the $\mathrm{U}-\mathrm{Pb}$ dating study [8]. Note that the $\mathrm{U}-\mathrm{Pb}$ age of Bed 25, the previously postulated boundary layer dated as $251.4 \pm 0.3 \mathrm{Ma}$ [5], has been revised to be $\sim 254 \mathrm{Ma}$ [8]. Such a significant bias is likely to result from the effect of $\mathrm{Pb}$ loss combined with varying amounts and sources of inheritance [8]. The complexities of accurately dating the Meishan boundary layers are further enhanced if one compares the data obtained by the $\mathrm{U}-\mathrm{Pb}$ and ${ }^{40} \mathrm{Ar} /{ }^{39} \mathrm{Ar}$ systems. For example, consideration of all the potential systematic uncertainties would expand the ${ }^{40} \mathrm{Ar} /{ }^{39} \mathrm{Ar}$ age error from \pm 0.2 to $\pm 4.6 \mathrm{Ma}$ for the $\mathrm{P}-\mathrm{T}$ samples dated $[8,12]$. It is beyond the scope of this paper to settle the 'inconsistencies' between the two dating systems, however, in the light of ${ }^{40} \mathrm{Ar} /{ }^{39} \mathrm{Ar}$ results based on the same calibration standard, our data suggest that the main eruption of the Emeishan Traps slightly predates the currently defined P-T boundary at Meishan and the main Siberian magmatism. The latter two are considered synchronous, despite the bias in $\mathrm{U}-\mathrm{Pb}$ dates [8], because high-precision ${ }^{40} \mathrm{Ar} /{ }^{39} \mathrm{Ar}$ data from the two areas are indistinguishable [6]. In contrast to the notion of extreme rapidity for the end-Permian extinction [5,7], Mundil et al. [8] proposed that the $\delta^{13} \mathrm{C}$ excursion was much longer $(\sim 1-2$ Myr instead of $165 \mathrm{kyr}$ in [5]) and the formation of the Meishan ash layers began $\sim 257 \mathrm{Ma}$ or even earlier. In this sense, our data are consistent with the hypothesis by Chung et al. [15], which argued for a causal link between the acidic eruptions in the Emeishan Traps and the P-T boundary ash beds widespread in South China. Additional ${ }^{40} \mathrm{Ar} /{ }^{39} \mathrm{Ar}$ and $\mathrm{U}-\mathrm{Pb}$ data for the ash layers in Meishan and other localities, as well as the Emeishan lavas, would certainly be required to further test such a hypothesis.

Although the eruption of the Siberian Traps is widely accepted to have played a key role in causing the environmental changes across the $\mathrm{P}-\mathrm{T}$ boundary, it can not be the only mechanism because the negative $\delta^{13} \mathrm{C}$ excursion was too large to be explained by any single event [5]. Prominent and rapid excursions in $\delta^{13} \mathrm{C}$ have been also reported at several periods in the geologic record, e.g., at $\sim 183 \mathrm{Ma}$ in the Jurassic [32], $\sim 120 \mathrm{Ma}$ in the Cretaceous [33] and $\sim 55 \mathrm{Ma}$ in the latest Paleocene [34,35], and these geochemical perturbations have been interpreted as consequences of massive release of methane stored in sedimentary gas hydrates beneath the sea floor [36]. According to the scenario of Dickens et al. [34], the methane would be oxidized to $\mathrm{CO}_{2}$ and higher $\mathrm{CO}_{2}$ concentrations in the ocean and atmosphere would lead to environmental catastrophes. All the $\delta^{13} \mathrm{C}$ excursions were associated with flood basalt eruptions that occurred, respectively, in the KarooFerrar, Ontong-Java and Kerguelen, and North Atlantic provinces [37]. The coincidences suggest a causal link between the two events and the generally discussed model is that massive volcanism in the marine realm warms and thus redirects surface water to past some critical threshold which, in turn, causes a circulation change, warming of intermediate water mass, thermal propagation into slope sediments, and dissociation of gas hydrates $[34,35,38]$. This raises an intriguing issue of whether a similar mechanism can be invoked at the P-T boundary [39]. An apparent drawback for the Siberian Traps is its within-continent occurrence. The Emeishan Traps, which were emplaced in the western margin of the South China Block where thick piles of marine limestone (the Maokou Formation) formed in association with a continental breakup [15], therefore, may serve as an appropriate trigger required for the chain reactions.

It is further noted that the Emeishan magma- 
tism, in comparison to two other possible mechanisms (the Siberian eruption and a bolide impact) proposed for the $\mathrm{P}-\mathrm{T}$ mass extinction and associated boundary events [5], better accommodates available geological data. Subaerial (withincontinent) eruption of the Siberian Traps, which could have injected large amounts of volcanic aerosols and sulfates to produce global cooling and acid rain $[6,9]$, has difficulties to form the boundary ashes in South China due to its distant location and the $\delta^{13} \mathrm{C}$ excursion resulting most likely from a blast of gas hydrates in the sea. Impact of a bolide or asteroidal body, on the other hand, does not satisfy the recurrent deposition of the volcanic ash beds. It is, moreover, not reconciled with the lack of iridium anomaly across the P-T boundary $[22,40,41]$. Given the fact that multiple interrelated events rather than a single mechanism would be necessary to interpret all the geological, geochemical and paleontological data regarding the greatest dying, it is suggested that by the latest Permian the biota had already declined as a result of progressive environmental deterioration due to intensive magmatic activity along the Panthalassan and Tethyan margins $[42,43]$. Under this circumstance, the beginning of the Emeishan magmatism may have led to massive release of methane and $\mathrm{CO}_{2}$ from the sea that initiated environmental collapse. Then, the successive eruptions in the Emeishan and Siberian traps across the $\mathrm{P}-\mathrm{T}$ boundary served combiningly as the final catalyst that pushed the most severe mass extinction in the history of the Earth.

\section{Acknowledgements}

We thank Drs. James K.W. Lee and S.-s. Sun for useful discussions, and Dr. G.S. Odin for providing the LP-6 biotite standard. Insightful and very constructive reviews provided by Drs. P.R. Renne, G. Dickens and an anonymous reviewer were of great help in clarifying a few points of this paper. This study benefitted from financial supports by the NSC research Grants (NSC89-2116M002-017 and NSC89-2116-M002-058).[BOY$L E]$

\section{References}

[1] D.H. Erwin, The Great Paleozoic Crisis: Life and Death in the Permian, Columbia University Press, New York (1993) 327 pp.

[2] D.H. Erwin, The Permo-Triassic extinction, Nature 367 (1994) 231-236.

[3] S.M. Stanley, X. Yang, A double mass extinction at the end of the Paleozoic Era, Science 266 (1994) 1340-1344.

[4] A.H. Knoll, R.K. Bambach, D.E. Canfield, J.P. Grotzinger, Comparative Earth history and Late Permian mass extinction, Science 273 (1996) 452-457.

[5] S.A. Bowring, D.H. Erwin, Y.G. Jin, M.W. Martin, K. Davidek, W. Wang, U/Pb zircon geochronology and tempo of the end-Permian mass extinction, Science 280 (1998) 1039-1045.

[6] P.R. Renne, Z.C. Zhang, M.A. Richards, M.T. Black, A.R. Basu, Synchrony and causal relations between Permian-Triassic boundary crises and Siberian flood volcanism, Science 269 (1995) 1413-1416.

[7] Y.G. Jin, Y. Wang, W. Wang, Q.H. Sheng, C.Q. Cao, D.H. Erwin, Pattern of marine mass extinction near the Permian-Triassic boundary in South China, Science 289 (2000) 432-436.

[8] R. Mundil, I. Metcalfe, K.R. Ludwig, P.R. Renne, F. Oberli, R.S. Nicoll, Timing of the Permian-Triassic biotic crisis: implications from new zircon $\mathrm{U} / \mathrm{Pb}$ age data (and their limitations), Earth Planet. Sci. Lett. 187 (2001) 131145 .

[9] I.H. Campbell, G.K. Czamanske, V.A. Fedorenko, R.I. Hill, Synchronism of the Siberian Traps and the PermianTriassic boundary, Science 258 (1992) 1760-1763.

[10] S.L. Kamo, G.K. Czamanske, T.E. Krogh, A minimum $\mathrm{U}-\mathrm{Pb}$ age for Siberian flood-basalt volcanism, Geochim. Cosmochim. Acta 60 (1996) 3505-3511.

[11] P.R. Renne, A.R. Basu, Rapid eruption of the Siberian Traps flood basalts at the Permo-Triassic boundary, Science 253 (1991) 176-179.

[12] P.R. Renne, C.C. Swisher, A.L. Deino, D.B. Karner, T.L. Owens, D.J. DePaolo, Intercalibration of standards, absolute ages and uncertainties in ${ }^{40} \mathrm{Ar} /{ }^{39} \mathrm{Ar}$ dating, Chem. Geol. 145 (1998) 117-152.

[13] M.F. Coffin, O. Eldholm, Large igneous provinces: Crustal structure, dimension, and external consequences, Rev. Geophys. 32 (1994) 1-36.

[14] S.L. Chung, B.M. Jahn, Plume-lithosphere interaction in generation of the Emeishan flood basalts at the PermianTriassic boundary, Geology 23 (1995) 889-892.

[15] S.L. Chung, B.M. Jahn, G.Y. Wu, C.H. Lo, B.L. Cong, The Emeishan Flood Basalt in SW China: a mantle plume initiation model and its connection with continental breakup and mass extinction at the Permian-Triassic boundary, in: M.F.J. Flower, S.L. Chung, C.H. Lo, T.Y Lee (Eds.), Mantle Dynamics and Plate Interactions in East Asia, AGU Geodyn. Ser. 27 (1998) pp. 47-58.

[16] V. Courtillot, C. Jaupart, I. Manighetti, P. Tapponnier, J. Besse, On causal links between flood basalts and con- 
tinental breakup, Earth Planet. Sci. Lett. 166 (1999) $177-$ 195.

[17] M.F. Zhou, J. Malpas, X.Y. Song, P.T. Robinson, A.K. Kennedy, M. Sun, G. Thompson, D. Yan, C.J. Zhang, SHRIMP Zircon Geochronology of the Emeishan Large Igneous Province (SW China): Implications for Double Mass Extinction in the Late Permian, 11th Goldschmidt Conf. (2001) Virginia, Abst. No. 3519.

[18] G.M. Thompson, J.R. Ali, X. Song, D.W. Jolley, Emeishan basalts, southwest China: Reappraisal of the formation's type area stratigraphy and a discussion of its significance as a LIP, J. Geol. Soc. Lond. 158 (2001) $593-599$.

[19] J.R. Ali, G.M. Thompson, X. Song, Y. Wang, Emeishan basalts (SW China) and the 'end-Guadalupian' crisis: Magnetobiostratigraphic constraints, J. Geol. Soc. Lond. 159 (2002) 21-29.

[20] A. Boven, P. Pasteels, L.E. Punsalan, J. Liu, X. Luo, W. Zhang, Z. Guo, J. Hertogen, ${ }^{40} \mathrm{Ar} /{ }^{39} \mathrm{Ar}$ geochronological constraints on the age and evolution of the Permo-Triassic Emeishan volcanic province, southwest China, J. Asian Earth Sci. 20 (2002) 157-175.

[21] H.F. Yin, S.J. Huang, K.X. Zhang, F.Q. Yang, M.H. Ding, X.M. Bie, The effects of volcanism on the PermoTriassic mass extinction in South China, in: W.C. Sweet, Z.Y. Yang, J.M. Dickins, H.F. Yin (Eds.), Permo-Triassic Boundary Events in the Eastern Tethys, Cambridge University Press, Cambridge (1992) pp. 146-157.

[22] L. Zhou, F.T. Kyte, The Permian-Triassic boundary event; a geochemical study of three Chinese sections, Earth Planet. Sci. Lett. 90 (1988) 411-421.

[23] Y.G. Xu, S.L. Chung, B.M. Jahn, G.Y. Wu, Petrologic and geochemical constraints on the petrogenesis of Permian-Triassic Emeishan flood basalts in SW China, Lithos 58 (2001) 145-168.

[24] J.Y. Lin, Spatial and temporal distribution of Emeishan basaltic rocks in the three southwestern provinces (Sichuan, Yunnan and Guizhou) of China, Chin. Bull. Sci. 12 (1985) 929-932.

[25] K.N. Huang, R.Y. Yang, X.C. Wang, Z.X. Huang, B.G. Liu, A preliminary study on trace element geochemistry of Emeishan Basalts from SW China (in Chinese), Acta Petrol. Sin. 4 (1988) 49-60.

[26] K. Huang, N.D. Opdyke, Magnetostratigraphic investigations on an Emeishan basalt section in western Guizhou Province, China, Earth Planet. Sci. Lett. 163 (1998) 1-14.

[27] G.S. Odin et al., Interlaboratory standards for dating purposes, in: G.S. Odin (Ed.), Numerical Dating in Stratigraphy, Wiley, Chichester (1982) pp. 123-149.

[28] A.K. Baksi, D.A. Archibald, E. Farrar, Intercalibration of ${ }^{40} \mathrm{Ar} /{ }^{39} \mathrm{Ar}$ dating standards, Chem. Geol. 129 (1996) 307-324.

[29] S.L. Chung, T.Y. Lee, C.H. Lo, P.L. Wang, N.T. Yem, T.T. Hoa, G.Y. Wu, Intraplate extension prior to conti- nental extrusion along the Ailao Shan-Red River shear zone, Geology 25 (1997) 311-314.

[30] A.R. Basu, R.J. Poreda, P.R. Renne, F. Teichmann, Y.R. Vasiliev, N.V. Sobolev, B.D. Turrin, High $-{ }^{3}$ He plume origin and temporal-spatial evolution of the Siberian flood basalts, Science 269 (1995) 822-825.

[31] A.R. Basu, P.R. Renne, D.K. Dasgupta, F. Teichmann, R.J. Poreda, Early and late alkali igneous pulses and a high- ${ }^{3} \mathrm{He}$ plume origin for the Deccan flood basalts, Science 261 (1993) 902-906.

[32] S.P. Hesselbo, D.R. Grocke, H.C. Jenkyns, C.J. Bjerrum, P. Farrimond, H.S. MorgansBell, O.R. Green, Massive dissociation of gas hydrate during a Jurassic oceanic anoxic event, Nature 406 (2000) 392-395.

[33] A.H. Jahren, N.C. Arenes, G. Sarmiento, J. Guerrero, R. Amundson, Terrestrial record of methane hydrate dissociation in the Early Cretaceous, Geology 29 (2001) 159162.

[34] G.R. Dickens, J.R. O’Neil, D.K. Rea, R.M. Owen, Dissociation of oceanic methane hydrate as a cause of the carbon isotope excursion at the end of the Paleocene, Paleoceanography 10 (1995) 965-971.

[35] M.E. Katz, D.K. Pak, G.R. Dickens, K.G. Miller, The source and fate of massive carbon input during the latest Paleocene thermal maximum, Science 286 (1999) 1533.

[36] K.A. Kvenvolden, Gas hydrates, geological perspective and global change, Rev. Geophys. 31 (1993) 173-187.

[37] J.J. Mahoney, M.F. Coffin, Large Igneous Provinces: Continental, Oceanic, and Planetary Flood Volcanism, AGU Geophys. Monogr. 100 (1997) 438 pp.

[38] G.R. Dickens, Methane oxidation during the late Palaeocene thermal maximum, Bull. Soc. Geol. Fr. 171 (2000) 37-49.

[39] E.S. Krull, G.J. Retallack, $\delta^{13} \mathrm{C}$ depth profiles from paleosols across the Permian-Triassic boundary: Evidence for methane release, Bull. Geol. Soc. Am. 112 (2000) 1459 1472.

[40] D.L. Clark, C.Y. Wang, C.J. Orth, J.S. Gilmore, Conodont survival and low iridium abundances across the Permian-Triassic boundary in South China, Science 233 (1986) 984-986.

[41] W.T. Holser, M. Magaritz, Cretaceous/Tertiary and Permian/Triassic boundary events compared, Geochim. Cosmochim. Acta 56 (1992) 3297-3309.

[42] J.J. Veevers, P.J. Conaghan, S.E. Shaw, Turning point in Pangean environmental history at the Permian/Triassic (P/ Tr) boundary, in: Pangea: Paleoclimate, Tectonics and Sedimentation During Accretion, Zenith and Breakup of a Supercontinent, Geol. Soc. Am. Spec. Paper 288 (1994) pp. 187-196.

[43] J.J. Veevers, R.C. Tewari, Permian-Carboniferous and Permian-Triassic magmatism in the rift zone bordering the Tethyan margin of southern Pangea, Geology 23 (1995) 467-470. 